\title{
Heterosis Studies in Ridge Gourd [Luffa acutangula (Roxb.) L.]
}

\author{
S.K. Bairwa ${ }^{1 *}$, A.K. Soni ${ }^{2}$ and A.S. Shekhawat ${ }^{3}$ \\ ${ }^{1}$ Department of Horticulture, College of Agriculture, Bikaner, Rajasthan, India \\ ${ }^{2}$ Department of Plant Breeding and Genetics, College of Agriculture, Bikaner, Rajasthan, India \\ ${ }^{3}$ Swami Keshwanand Rajasthan Agricultural University, Bikaner, Rajasthan, India \\ *Corresponding author
}

\section{A B S T R A C T}

\section{Keywords}

Ridge gourd, Yield, Diallel, Heterosis, Hybrids.

\section{Article Info}

Accepted:

12 September 2017

Available Online:

10 November 2017
A study was carried out on heterosis for fruit yield and yield related traits in ridge gourd. Twenty eight $F_{1}$ hybrids were generated by half diallel (excluding reciprocals) mating design. These $F_{1}$ hybrids along with eight parents were evaluated in randomized block design with three replication at Horticulture farm, College of Agriculture, Bikaner and KVK farm, Bhartiya Krishi Vigyan Kendra, Fatehpur-Shekhawati, Sikar. The maximum positive heterosis was observed in the crosses maximum standard heterosis (85.29 $\%)$ followed by cross Jaipuri Long x Arka Sujath $(81.85 \%)$ in $\mathrm{E}_{4}$ whereas maximum heterobeltiosis Jaipuri Long x Swarna Manjari depicted (63.82 $\%$ ) in $\mathrm{E}_{4}$ followed by cross Swarna Uphar x Jaipuri Long (40.58 \%) for total fruit yield per vine.

\section{Introduction}

Ridge gourd [Luffa acutangula (Roxb.)L.] is considered as one of the most important cucurbitaceous vegetable crops both nutritionally and economically. Its tender fruits are well known for culinary vegetable in India with good nutritive value and high yield potential, which are rich in vitamin A, vitamin $\mathrm{C}$ and iron (Yawalkar, 2004) and have certain medicinal uses too. Hayes and Jones (1916) were the earliest investigators to export heterosis in cucurbits. The different size of fruits indicates about its wide genetic variability (Irulappan, 1992). For its being a monoecious and essentially cross pollinated crop, it has ample scope for successful exploitation of hybrid vigour. Aiming, this present investigation was undertaken with an objective to select elite parental line which can be best utilized for hybridization programmes yielding best performing hybrids for commercial cultivation in India as there is still a least availability of varieties and hybrids of this crop.

\section{Materials and Methods}

The present investigation was carried out during summer season and rainy season (2011) at Horticulture farm, College of Agriculture, Bikaner and KVK farm, Bhartiya 
Krishi Vigyan Kendra, Fatehpur-Shekhawati, Sikar. The experimental material for the present study consisted of eight diverse genotypes viz., Pusa Nasdar, Swarna Uphar, Swarna Manjari, AHRG-1, Salumber Long, Jaipuri Long, Arka Sujath and Arka Sumeet. These eight genotypes were crossed in all possible combinations excluding reciprocals during summer season (2011) to produce $F_{1}$ 's seed by hand pollination. Eight parents and their 28 crosses were tested in randomized block design (RBD) with three replication and four environments, created by two different date(s) of sowing $\left(5^{\text {th }}\right.$ and $25^{\text {th }}$ July, 2011) at two different location (Bikaner and Fatehpur Shekhawati, Sikar). Observations were recorded on five randomly selected plants from each treatment for fruit yield, yield related traits and quality traits viz., number of node at which first female flower appears, days to opening of first female flower, days to first fruit harvest, number of fruits per vine, fruit length $(\mathrm{cm})$, fruit weight $(\mathrm{g})$, total fruit yield per vine $(\mathrm{kg})$ and crude fiber content $(\%)$ at harvest. The heterosis over better and top parent was estimated for these traits in each environment as well as over the environments.

\section{Results and Discussion}

Earliness, which is considered as one of the most important parameters in hybrids was decided upon as it's indicated by number of node at which first female flower appears, days to opening of first female flower and days to first fruit harvest (Table 1 and 2). The best cross, which gave highest performance over mid parent in relation to earliness was found in cross Swarna Uphar $x$ Salumber Long $(-26.18 \%)$ in $\mathrm{E}_{1}$, Pusa Nasdar x Swarna Uphar $(-27.19 \%)$ in $E_{2}$ and Pusa Nasdar $x$ Swarna Uphar $(-24.62 \%)$ in $\mathrm{E}_{4}$ for number of node at which first female flower appears; Swarna Manjari x Arka Sujath $(-25.71 \%)$ in $\mathrm{E}_{1}$, Salumber Long x Arka Sumeet (-24.20 \%) in $E_{2}$, Swarna Uphar $x$ Arka Sumeet (-
$24.26 \%)$ in $E_{3}$ and Swarna Uphar $x$ Arka Sumeet (-13.35) in $\mathrm{E}_{4}$ for days to opening of first female flower and Swarna Manjari $\mathrm{x}$ Arka Sujath (-22.95\%) in $\mathrm{E}_{1}$, Salumber Long $\mathrm{x}$ Arka Sumeet $(-20.79 \%)$ in $\mathrm{E}_{2}$ and Pusa Nasdar x Arka Sumeet (-11.61\%) in $\mathrm{E}_{4}$ for days to first fruit harvest. Significant maximum negative heterobeltiosis over their better parent was recorded in the cross Swarna Uphar x Salumber Long (-27.12\%) in $\mathrm{E}_{1}$, Swarna Uphar $\mathrm{x}$ Salumber Long ($33.37 \%)$ in $\mathrm{E}_{2}$, Swarna Uphar x AHRG-1 ($20.52 \%)$ in $E_{3}$ and Pusa Nasdar $x$ Swarna Uphar (-29.55) in $\mathrm{E}_{4}$ for number of node at which first female flower appears; Swarna Manjari $\mathrm{X}$ Arka Sujath (-31.24\%) in $\mathrm{E}_{1}$, Swarna Uphar x Arka Sumeet (-28.24\%) in $\mathrm{E}_{2}$, Swarna Uphar x Arka Sumeet (-36.05\%) in $\mathrm{E}_{3}$ and Pusa Nasdar $\mathrm{x}$ Arka Sumeet ($22.02 \%$ ) in $\mathrm{E}_{4}$ for days to opening of first female flower and cross Swarna Manjari $x$ Arka Sujath (-28.27\%) in $\mathrm{E}_{1}$, Swarna Uphar $\mathrm{x}$ Arka Sumeet $(-24.12 \%)$ in $\mathrm{E}_{2}$ and Pusa Nasdar x Arka Sumeet (-19.22\%) in $\mathrm{E}_{4}$ for days to first fruit harvest. Naliyadhara et al., (2007) reported heterosis for earliness in sponge gourd. Similar type of appreciable heterosis for number of node at which first female flower appears, days to opening of first female flower and days to first fruit harvest in ridge gourd have also been found by Karmakar et al., (2014) and Poshiya et al., (2015).

(Table 1 and 2) indicate that number of fruit per vine, fruit length and fruit weight are the direct component of fruit yield in ridge gourd. For fruit length Jaipuri Long $x$ Swarna Manjari (76.10\%) in $\mathrm{E}_{1}$, Pusa Nasdar x Arka Sujath $(37.66 \%)$ in $\mathrm{E}_{3}$ and AHRG-1 $\mathrm{x}$ Arka Sumeet $(33.91 \%)$ in $\mathrm{E}_{4}$ had highest heterosis. $\mathrm{F}_{1}$ hybrid Swarna Manjari x Arka Sumeet $(33.97 \%)$ in $E_{1}$, AHRG-1 x Swarna Manjari $(32.26 \%)$ in $E_{2}$, Pusa Nasdar x Jaipuri Long $(14.82 \%)$ in $E_{3}$ and Swarna Uphar $x$ Arka Sujath $(20.53 \%)$ in $\mathrm{E}_{4}$ exhibited maximum heterosis for fruit weight. 
Table.1 Range of heterosis of different character under different environmental condition of 28 F's of ridge gourd

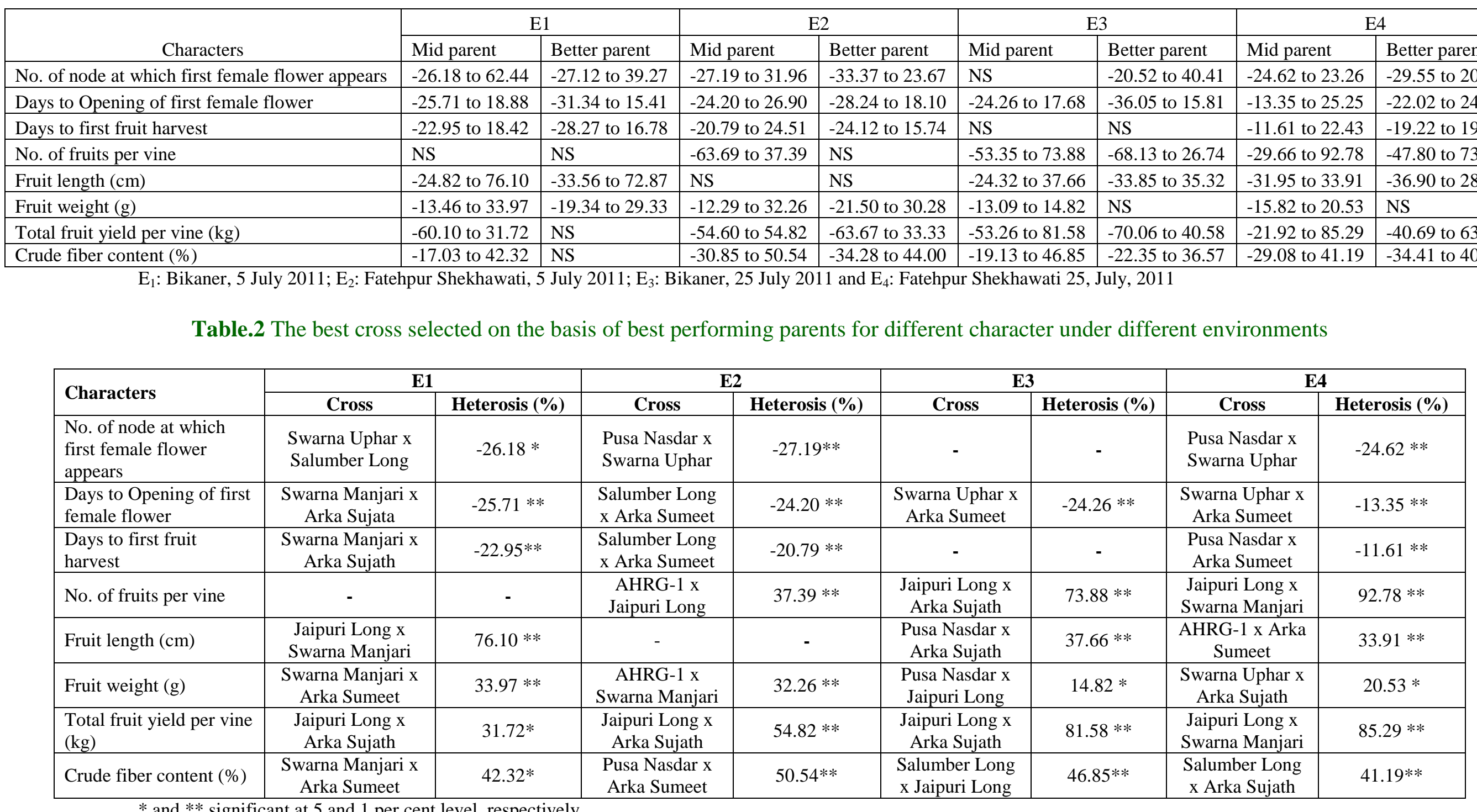

$*$ and ** significant at 5 and 1 per cent level, respectively

$\mathrm{E}_{1}$ : Bikaner, 5 July 2011; $\mathrm{E}_{2}$ : Fatehpur, Shekhawati 5 July 2011; $\mathrm{E}_{3}$ : Bikaner, 25 July 2011 and $\mathrm{E}_{4}$ : Fatehpur Shekhawati 25, July, 2011 
Cross like AHRG-1 x Jaipuri Long (37.39\%) in $\mathrm{E}_{2}$, Jaipuri Long $\mathrm{x}$ Arka Sujath (73.88\%) in $\mathrm{E}_{3}$ and Jaipuri Long $\mathrm{x}$ Swarna Manjari $(92.78 \%)$ in $\mathrm{E}_{4}$ was found to be heterotic combination for number of fruit per vine. For total fruit yield per vine, $\mathrm{F}_{1}$ hybrid Jaipuri Long x Arka Sujath (31.72\%) in $\mathrm{E}_{1}$, Jaipuri Long $x$ Arka Sujath (54.82\%) in $\mathrm{E}_{2}$, Jaipuri Long $x$ Arka Sujath $(81.58 \%)$ in $\mathrm{E}_{3}$ and Jaipuri Long x Swarna Manjari (85.29\%) in $\mathrm{E}_{4}$. For fruit length significant positive heterobeltiosis was observed for Jaipuri Long $\mathrm{x}$ Swarna Manjari $(72.87 \%)$ in $\mathrm{E}_{1}$, Pusa Nasdar x Arka Sujath (35.32\%) in $\mathrm{E}_{3}$ and AHRG-1 x Arka Sumeet (28.15\%) in $\mathrm{E}_{4}$; whereas Swarna Manjari x Arka Sumeet in $\mathrm{E}_{1}$ and AHRG-1 $x$ Swarna Manjari in $E_{2}$ exhibited higher heterobeltiosis for fruit weight. For number of fruits per vine AHRG1 x Swarna Manjari (26.74\%) in $\mathrm{E}_{3}$ and Jaipuri Long x Swarna Manjari (73.38\%) in $\mathrm{E}_{4}$ have highest heterobeltiosis. $\mathrm{F}_{1}$ hybrids Swarna Uphar x Jaipuri Long (33.33\%) in $\mathrm{E}_{2}$, Swarna Uphar x Jaipuri Long (40.58\%) in $\mathrm{E}_{3}$ and Jaipuri Long x Swarna Manjari (63.82\%) in $\mathrm{E}_{4}$ exhibited highest heterobeltiosis and some other crosses like AHRG-1 x Swarna Uphar in $\mathrm{E}_{2}$, Swarna Uphar x Jaipuri Long in $E_{2}$ and $E_{3}$, Jaipuri Long $x$ Swarna Manjari, Swarna Uphar x Arka Sujath, Pusa Nasdar x Jaipuri Long, Pusa Nasdar x Swarna Manjari in $\mathrm{E}_{4}$ exhibited significant positive heterobeltiosis for total fruit yield per vine. These results are conformity with the studies of Tyagi et al., (2010), Anand (2012), Reddy et al., (2013), Karmakar et al., (2014), Koppad et al., (2015) and Poshiya et al., (2015) who have reported a positive and significant standard heterosis for fruit length and total fruit yield found in ridge gourd.

Occurrence of good crude as indicator its good quality of fruits was also evident by positive heterosis as indicated in Table 1 and 2. The maximum positive heterosis was observed for crude fiber in tender fruits in crosses like Swarna Manjari x Arka Sumeet (42.32\%) in $\mathrm{E}_{1}$, Pusa Nasdar x Arka Sumeet $(50.54 \%)$ in $\mathrm{E}_{2}$, Salumber Long $\mathrm{x}$ Jaipuri Long $(46.85 \%)$ in E3 and Salumber Long $\mathrm{x}$ Arka Sujath $(41.19 \%)$ in $\mathrm{E}_{4}$ was reflected for crude fiber in tender fruits. Whereas cross Pusa Nasdar x Arka Sumeet $(44.00 \%)$ in $\mathrm{E}_{2}$, Salumber Long x Swarna Manjari (36.57\%) in $E_{3}$ and Salumber Long $x$ Arka Sujath $(40.77 \%)$ in $\mathrm{E}_{4}$ exhibited significant positive heterobeltiosis for crude fiber (\%) in tender fruits.

\section{Acknowledgements}

I thankfully acknowledge to the University Grand Commission, New Delhi for providing fellowship during my $\mathrm{Ph} . \mathrm{D}$ programme, also thankful to the Director Extension, SKRAU, Bikaner, The Director, IARI, New Delhi, The Director, CIAH, Bikaner, The Director, IIHR Bangalore and The Director, ICAR-NorthEastern Region, Plandu (Ranchi) and the Head of the Department, RCA, Udaipur for providing the seeds of different Ridge gourd genotype.

\section{References}

Anand, N. 2012. Heterosis and combining ability in ridge gourd. M.Sc. (Hort.) Thesis, Univ. Hort. Sci. Bagalkot.

Hayes, H.K. and Jones, D.F. 1916. First generation crosses in cucumber. Ann. Rep. Conn. Agric. Expt. Station: 319322.

Irulappan. I. 1992. Genetic diversity in cucurbits. (Luffa acutangula Roxb. L.). Indian J. Hort. 37(1):1-2.

Karmakar, Pradip, Munshi, A.D., Behera, T.K. and Sureja, A.K. 2014. Heterosis in ridge gourd (Luffa acutangula Roxb.) using hermaphrodite lines. Indian $J$. Hort. 71 (1): 61-66.

Koppad S. B., Chavan M. L. and Hallur R. 2015. Line $x$ tester analysis of 
physiological traits for fruit yield and related characters in Luffa acutangula (Roxb.) L. The Bioscan. 10(2): 527-534.

Naliyadhara, M.V., Dhaduk, L.K., Barad, A.V., Puroith, V. L., and Vachhani, J.H. 2007. Heterosis for yield and its component in sponge gourd [Luffa cylindrica (Roem.)]. National J. Plant Improv. 9: 132-135.

Poshiya, S.C., Dhaduk, L.K., Raval L. and Metha, D.R. 2015. Heterosis in ridge gourd [Luffa acutangula (Roxb.) L.]. Electronic J. Plant Breeding. 6(2):581585.

Reddy, K. P., Reddy, V. S. K. and Padma, S.
S. V. 2013. Performance of parents and hybrids for yield and yield attributing characters in ridge gourd (Luffa acutangula (Roxb.) L.). The Bioscan. Supplement on Genetics \& Plant Breeding. 8 (4): 1373-1377.

Tyagi, S. V. S., Sharma, P., Siddiqui, S. A. and Khandelwal, R. C. 2010. Combining ability for yield and fruit quality in Luffa. Int. J. of Veg. Sci. 16 (3): 267-277.

Yawalkar, K.S. 2004. Cucurbitaceous or vine crops. Vegetable Crops of India, (V. Ed.). pp. 152-155.

\section{How to cite this article:}

Bairwa, S.K., A.K. Soni and Shekhawat, A.S. 2017. Heterosis Studies in Ridge Gourd [Luffa acutangula (Roxb.) L.]. Int.J.Curr.Microbiol.App.Sci. 6(11): 1572-1576. doi: https://doi.org/10.20546/ijcmas.2017.611.188 